\title{
Farmers' Household Livelihood Resilience In The Lake Tempe Area
}

${ }^{1}$ A. Besse Dahliana, ${ }^{2}$ Saleh S. Ali, ${ }^{3}$ Darmawan Salman, ${ }^{4}$ EymalBahsar Demmallino, ${ }^{5}$ AS.Halimah

${ }^{1}$ Department of Agribusiness, College of Agricultural Sciences YAPI-Bone, Indonesia .

${ }^{2}$ Department of Agricultural Social-economics, Faculty of Agriculture, Hasanuddin University, Makassar,Indonesia

${ }^{3}$ Department of Agricultural Social-economics, Faculty of Agriculture, Hasanuddin University, Makassar,Indonesia

${ }^{4}$ Department of Agricultural Social-economics, Faculty of Agriculture, Hasanuddin University, Makassar,Indonesia

${ }^{5}$ Department of Agribusiness, Muhammadiyah University of Parepare, Indonesia

Correspondence Author: AS.Halimah, Muhammadiyah University of Parepare, Department of Agribusiness, Indonesia

Telp :+62-81343996358; E-mail: ima_gaansil@yahoo.co.id

Received date: 23 January 2018, Accepted date: 27 March 2018, Online date: 10 April 2018

Copyright: (C) 2018 A. Besse Dahliana et al. This is an open-access article distributed under the terms of the Creative Commons Attribution License, which permits unrestricted use, distribution, and reproduction in any medium, provided the original author and source are credited.

\begin{abstract}
The lakeside community is part of lake management that not only consider the ecological, cultural, but also economic aspects where the economic aspect is intended to raise the incomes which may then improve the farmers' welfare, so that their household not only use natural capital in livelihood activities, but also use other livelihood capitals to produce income. The study aims to know farmers' household livelihood resilience that is correlated with their livelihood capital. Through the combination of a quantitative approach by asking questionnaires and a qualitative with in-depth interviews with farmer stilling the fields around the lake, their activity for their livelihood resilience can be revealed. The results showed that the level of income was strongly correlated with the level of resilience,it is mean that the higher the level of incomes, the higher the level of resilience will be. Good incomes may influence a family's saving capacity so that the saving may serve as valuable assets for a family used during critical economic condition.No households are collapsed during crises,it is caused by the fact that the households' incomes are not from one sector; they adopt a multi-livelihood pattern. The household resilience is various in forms namely making use of savings and loan, social capital, skills besides agricultural sector, cattle, valuable assets such as land, houses, jewelry and vehicles. Another factor that cause the households to have such resilience is high possession of social capital. The research suggests that resilienceis affected by the ownership of livelihood capital and household incomes. Livelihood capitals can build the household resilience for the lakeside community.
\end{abstract}

Key words: Resilience, livelihood capitals, Lake Tempe

\section{INTRODUCTION}

Indonesia is endowed with at least 521 natural lakes [4], and almost all of the lakes give very important supports for the livelihood of the people. In the 16th World Lake Conference held in 2016 it was mentioned that the host country Indonesia has over 1,500 lakes in total (covering both small and large ones). They support local livelihood and socio-economic development, e.g., by providing hydropower and irrigation/industrial water, mitigating flood damage, promoting tourism, etc. In Africa, the lakes are highly productive centres of biodiversity providing ecosystem services including food, water for domestic use, agriculture, fisheries, recreation, and transportation[14]. Moreover Indonesian lakes are used mainly for hydro-power electricity [21].

The LakeTempe is one of these lakes which has become a source of livelihood for people who live on the edge of the lake. Lake resources have many usages which bring great benefits, especially for the community who live around it[16].The economic potential in the area of Lake Tempe was mainly used for fisheries and agriculture activities, where in 1957 and 1959 fishery production reached 50000 tons/year, but decreased in the period between 1999 and 2000 , which only reached 17000 tons/year [24]. In the period from 2001 to 2005, there was an average production decline of $6.45 \%$ per year. Due to the changing conditions, both physically natural and human activities, the productivity of the lake is currently continuously decreasing. The production of general aquatic fishery products in three districts in the area of Lake Tempe in 2010 was recorded to be 11272 ton/year [6].

The people who live around Lake Tempe are very dependent on the existence and condition of the lake water [12]. It is as depicted Okpara, et.al. (2016) that the water lake fluctuations influence livelihoods like as happened in Lake Chad in the Republic of Chadwhere there is an opportunity for lakeshore dwellers to access under lake and the opportunity is loss caused by lake drying. Lake drying affectfor their household livelihoods.

The Community is highly dependent on the existence of Lake Tempe especially in terms of their livelihood as farmers and fishermen. They survive although every year there is a risk of flooding that must be faced as a result of silting the lake. Even, the conditions of Tempe Lake in generally thatWhen the flood occurred, the Tempe Lake area becomes 30,000 hectares, but when the drought occurs, the width of the lake shrinksinto 10,000 ha.It is found that the silting is 15 $20 \mathrm{~cm}$ and it tends to increase every year, with a maximum depth at the peak of the dry season of only about $0.5 \mathrm{~m}$ and an average decrease of $1.48 \mathrm{~km} / \mathrm{year}$, so it is predicted that the lake Tempewill be lost on peak of the dry season in 2018[22]. The complex interactions between environment and society influence the degree to which regional livelihoods may be vulnerable or resilient to disruption and also illustrate that vulnerability to change can lead to improved understanding of risk and increased adaptive capacity[9].

Such a natural condition, as described above, requires the farmers around the lake to be able to adapt and to create various ways to survive. Although it is known that if the farmers are greatly influenced by the tidal of the lake, they must have a high resilience as realized in their household livelihood strategies. 
Citation: A. Besse Dahliana, Saleh S. Ali, Darmawan Salman, EymalBahsar Demmallino, AS.Halimah, 2018. Farmers' Household Livelihood Resilience In The Lake Tempe Area. Advances in Environmental Biology., 12(3): 1-4.

Dharmawan (2006) explained that a livelihood strategy is not limited to theliving, but to more life strategies. Moreover, according to him, the sources of livelihoods are multiple, since households are not only dependent upon one job, since one source of livelihood cannot cover all needs of households.

Livelihood strategy is not merely a means of living as the livelihood. The term livelihood strategy is a strategy to construct the life system, how to survive, or how to improve the status of life. Livelihood strategy will be made by anyone in the whole life. When someone or a household faces a crisis or shock, their position will be unstable. Then they will try to survive and to return to their original position. This ability is then called livelihood resilience. Livelihood strategy applied by each household will be different during the normal and critical conditions. Critical condition will require a household to do more in order to be able to face the crisis [7].

Livelihood strategy is the way a household build a livelihood system, the way to survive or to improve the status of life. A household builds a livelihood strategy by making use of the livelihood assets it possesses [20]. A livelihood strategy is a series of choices of livelihood and activities covering various rational actions a household takes to reach a goal that has been formulated. Any action made deals with the use of the resources or assets [8]. This livelihood strategy is various in each region and individual. It is in line with the statement made by Turasih and Adiwibowo[25] that the choice of livelihood strategy is really determined by the availability of resources and the ability to access the livelihood sources.

Within the field of development, the sustainable livelihoods perspective has evolved considerably during the past two decades. A livelihood is understood to comprise 'the capabilities, assets (stores, resources, claims and access) and activities required for a means of living [5, 23]

According to Adger[1], resilience is the opposite from vulnerability, where the two concepts are like one coin with two sides. The concept of resilience is a wide concept, where the concept includes the capability and ability to respond in a critical situation or an emergency situation. Resilience is the ability to survive and to return to the original position when a critical event occurs. Therefore, resilience is a dynamic process covering any positive adaptations when a disaster happens. Resilience during a disaster is the ability to prevent or protect from any attacks or threats with high risks and incidents. Resilience has commonly been presented as a positive attribute, as the opposite of vulnerability, and used to understand adaptive capacities to tackle the impacts, shocks and stresses of climate change[23].Resilience is an ability of a system to absorb any disorders and reorganize them when it is changing so that it still maintains its basic function. Livelihood resilience is seen as a household's ability to face economic crises or shocks so that it may still be able to survive, to be in a stable position, and it will not experience a long standing crisis and starvation. The form of this resilience varies according to the resources it possesses [27].

Like in happen the Vietnamese Mekong River Delta, although people have experienced the impact of floods for years, some adapt well, but others are vulnerable to floods. Resilience to floods is a useful concept to study the capacity of rural households to cope with, adapt to, and benefit from floods. Knowledge of the resilience of households to floods can help disaster risk managers to design policies for living with floods[18]. Whereas in South Africa, to building livelihood resilience while providing pathways for households to escape poverty through enhancing the multiple benefits of livestock, adding value to secondary rangeland resources, and expanding the rural non-farm economy, the people should take multi-faceted approach. Livestock farming in communal areas is an activity pursued by rural households as one of a range of livelihood strategies, caused the cash and non-cash benefits derived from livestock, as well as the wide range of secondary resources harvested from communal rangelands, make an important contribution to livelihood diversification, and hence, resilience[26].

While according toAdger et al [2], social and ecological vulnerability to disasters and outcomes of any particular extreme event are influenced by buildup or erosion of resilience both before and after disasters occur. Resilient social-ecological systems incorporate diverse mechanisms for living with, and learning from, change and unexpected shocks. Disaster management requires multilevel governance systems that can enhance the capacity to cope with uncertainty and surprise by mobilizing diverse sources of resilience. And Hang [11], the factors affecting on resilience of household include assets base and perception or attitude of household about risks as well as the ability to learn and gain from changes. In fact [3] , households belonging to different socio-economic groups have different strategies to earn their own living which, in turn, may ensure different levels of resilience.

Three key findings emerge about livelihoods resilience and access to natural capital for migrants and non-migrants in Madagaskar. First, higher levels of proximate natural resources are associated with greater financial, human, and social capital for both migrants and non-migrants. Second, migrants have on average, greater financial, physical, human, and social capital than non-migrants, and urban-to-rural migrants do exceptionally well on all capital asset categories. Third, migrants residing in areas with higher levels of natural capital tend to have significantly higher levels of human capital (education) [17]. That is mean that increasing capital reduces vulnerability and strengthens resilience[13].

There many hindrances faced by the farmers dwelling around the lake, besides natural factors, namely natural disasters and the natural condition that does not support them, there are also other factors namely the increased life needs and any other needs that should be fulfilled by households. They should have resilience to survive. Based on the descriptions above, this present research would be focused on understanding the forms of the livelihood resilience of the farmers dwelling around the Lake Tempe related to the household capitals they possess.

\section{Method:}

This research was conducted in the area of the Tempe Lake and its surrounding areas in the District Marioriawa, Soppeng regency, South Sulawesi Province, Indonesia. It is known that administratively the area of Tempe Lakecovers 3 districts, namely Wajo (54.6\%), Sidrap (34.6\%) and Soppeng (10.7\%).Data collection techniques employed were observations, interviews, and documentation to accomplish the objective of this study. The study was focused on Kaca village because the village is the site nearest from the lake. The data analyses adopted were qualitative and descriptive in nature, covering data reduction, data display, and conclusion drawing [15]. Descriptive and qualitative research techniques were used to determine the pattern of the farmers around Lake Tempe when the lake's water flood and recedes to their fields for the resilience of their livelihood. The sampling technique used was incidental sampling technique where any farmers who accidentally / incidentally met with investigators were used as informants, when it is considered that the coincidence is found to be suitable as a data source. Incidental sampling method was selected because it is difficult to meet potential informants, they generally were only in their houses in the evening. Informants being interviews consisted of the farmers tilling of field around the lake, village chiefs, the subdistrict head, and head of the Department of Tourism as the holder of the license. The informants were determined using the snowball sampling technique, namely the determination of the informant or respondents based on previous informants without specifying the exact numbers, namely informants who had been in line with the purpose and the need for research [10].

\section{RESULTS AND DISCUSSION}

Household Livelihood Capital of the Farmers around the Lake Tempe:

A household should have capitals in order to make various strategies in earning the living. The capitals are used to do activities to fulfill various elements of needs of the farmers and their families. The capitals possessed by the farmer's households in the research site are natural, human, physical, financial and social ones.

Natural capital in this present research was measured based on the land control by farmers. The research results showed that in general such a land control influences the level of farmer households' incomes. The wider the land controlled, the higher the level of the incomes of the farmer households. Generally, the farmers control the land around the lake based on their heritance, although some informants said that the right for land was obtained through buy and sell processes. This might happen since the majority of farmers in this area are the native people, while some new comers dwelling and becoming farmers admitted that they controlled the land buying it.

Human capital may be measured based on the age, education level, skills possessed, and the number of family members who are working. In general, most respondents $(60 \%)$ were under the age category of $46-60$ years, $27 \%$ under age category of $25-45$ years and $13 \%$ under the age category of over 60 years. Education level also influences the activity of fulfilling household needs. It can be seen from the respondents with Senior High School Education level who had many alternative jobs, such as being assistant teachers in elementary schools, or assistant staffs in village or kelurahan offices. There was just $5 \%$ respondents who had skills besides farming or fishing such as carpenters or builders. The level of incomes is also influenced by the number of household members who work, meaning that a household which is dependent upon one person to earn a living tend to be weak in the economic condition compared with the household with more than one persons who are earning a living. This present research explained that if the majority of households in this did not merely depend on the head of household in earning a living, but also involved wives and adult children. 
The indicators of the physical capital in this present research were the width of the land, cattle, and vehicle possession. The research results showed that $55 \%$ respondents controlled 0.5-1 ha. There were three forms of the land namely: their own land, land with profit sharing system, and leased land. Another asset in the form of cattle showed that most households (80\%) possessed cows or goats, where they thought that cows or goats are considered as their savings for emergency needs. Most households (95) possessed motorized vehicles such as motorcycles, cars or trucks with the composition of 65 motorcycles, $35 \%$ cars, and 5\% trucks. According to the respondents, the vehicles served as their transportation tools namely to pick up their yields to the market when the lake recedes. When the lake is high in its tide, they used them to vendor their fishes or even to pick up passengers (ojek-- motorcycle taxi).

Access to loan and saving capacity are financial capital for the community around the lake. Access to loan is neighbors and relatives (76). Neighbors are more trusted and easier than banks (24\%). The people around the lake generally borrowed money or rice to for their daily needs. The level of their saving capacity also varied. $30 \%$ households could not save their savings, $18 \%$ households did not routinely save their incomes and $52 \%$ households could routinely save their incomes. The ability to save for the farmer households could be seen from the difference between their total incomes and expenses, meaning that if the difference is higher, it must influence the amount of incomes saved. In general, each household has a different saving capacity, where the amount of money saved will influence the sustainability of the households. The higher the saving capacity a household has, the stronger its ability in facing crises.

The description about togetherness based on trust and mutual cooperation prevailed as the social norm, is part of social capital shown by the community dwelling in lake Tempe. All respondents had a relationship one and another. This shows that their social life is still very good. The condition enabled them to unite and contribute to fulfill their needs and to improve their incomes together, including under critical condition.

Farmers' Household Livelihood Resilience in the Lake Tempe Area:

Resilience made by the farmers generally used their livelihood capital. The respondents described the resilience as an alternative choice they really depended on when a critical condition occurred in the forms of among others the use of the savings and loan, social capital, skills in other than those in the agricultural sector, cattle, valuable assets, land, house, jewelry and vehicles.

The use of saving by the households possessing the capacity in saving their incomes routinely enabled them to manage activities to fulfill their daily needs during critical condition. It is known that the community in the side of the lake Tempe had a high level of dependence on the tidal condition of the lake. For the community dwelling in the research site, flood risks due to the stilling of the lake Tempe had been faced almost each year. This condition made them try to save their incomes as their preparation to face the flood. Some of them used loan as their last alternative to fulfill their needs during and post floods. The income management during a critical condition is an important factor for the households to be able to survive.

Reciprocal relation becomes a valuable social capital. This kind of capital is important especially during difficult time. it can be seen from the answers given by the respondents that they preferred to borrow money or to get help from their neighbors or relatives to meet their household livelihood. They usually borrowed money in limited amount. Some of them exchanged food materials to be able to be cooked and shared together, even when a household had excessive foods, they shared them. The relationship was based on the trust between one and another, the emphatic attitude and behavior to help others and on various efforts to fulfill their needs together. The norms regulating their social patterns, although they are not written, had been understood to be the determinant of good behavior patterns in the context of social relation, therefore, social sanctions occurred if one broke them. The social norm would give positive impacts for the development of the community. The condition may still be shown among the community dwelling in the side of the lake Tempe, especially those in the research site.

The farmers' other skills besides farming and fishing, may be beneficial when the agricultural sector will not become the main promising source to fulfill their households' needs. There were respondents possessing skills as carpenters and builders they could use as their other sources of incomes to support their household livelihood. Some respondents explained that the people living at the side of the lake Tempe made use of their motorcycles as the ojek out of their villages.

Cattle ownership for the households in the research site also becomes the assets that may be sold whenever they need money. This is because it is very easy to sell cattle and the results of selling cattle may be saved for other needs. Some respondents admitted that they sold their cattle, either cows or goats, to other villages during critical times and then they saved some of the money to buy younger cattle. Therefore they did not directly lose their cattle. They said that they just replace their older cattle with the younger ones.

The last alternative choice the respondents usually did during critical times at the side of the lake Tempe was to sell some of their land, houses, jewelry, and vehicles they possessed. The first choice the respondents made generally was to sell their jewelry to stabilize their households. While it rarely happened that the respondents sold their houses except they had other houses besides the one he lived in. Respondents also admitted that they savings were gold and land since the two assets have increasing selling values.

The Correlation between Livelihood Capital and Incomes Possession and Resilience:

Household livelihood resilience is influenced by incomes and livelihood capital possession. It means that the higher the level of the livelihood capital possession and the level of the incomes, the higher the level of the household resilience will be. In general, the five capitals and incomes are related to household resilience, but from the results of the Rank Spearman correlational test, it was shown that capital which is not really correlated with resilience was human capital with significance of $0.621(>0.01)$. In this present research, age, education level, skills possessed, and the number of family members did not give significant effects on the livelihood activities and household incomes. Almost all respondents worked as farmers and fishermen so that they assumed that if their education level did not significantly influenced their incomes.

The correlation between natural, physical, financial, and social capitals and the level of resilience was real (sig $<0.01)$. The financial capital showed a strong correlation (the coefficient value of 0.512 ). The financial capital such access to loan and saving could be greatly used by households to fulfill their needs. Meanwhile the physical, natural and social capitals showed moderate correlations (with coefficient values between 0.355 and 0.415 ). The physical capital (land, vehicles, and cattle) and natural capital (land) could be sold anytime as needed. The stuffs could used the households' assets that could also be considered as saving.

Social capital such as trust, mutual cooperation based on the prevailed social norm, may be made use of to support the financial capital such as the access to loan. Mutual cooperation strongly influenced the access of households to obtain aids from neighbors and relatives. But the level of the livelihood capital possession showed a strong correlation $(\mathrm{sig}<0.619)$ with resilience. This shows that the livelihood capital influenced the household resilience level.

Besides livelihood capital, household resilience is also influenced by incomes. Smaller livelihood sources would influence the farmers' household income level. Based on the correlational test, it is shown that the level of income was strongly correlated with the level of resilience with the coefficient value of 0.617 . This shows that the higher the level of incomes, the higher the level of resilience will be. Good incomes may influence a family's saving capacity so that the saving may serve as valuable assets for a family used during critical economic condition.

\section{Conclusion:}

It can be concluded that all households existing in Kaca are those with a good ability to survive during critical economic condition. No households are collapsed during crises. It is caused by the fact that the households' incomes are not from one sector; they adopt a multi-livelihood pattern. The household resilience is various in forms namely making use of savings and loan,social capital, skills besides agricultural sector, cattle, valuable assets such as land, houses, jewelry and vehicles. Another factor that cause the households to have such resilience is high possession of social capital. This social capital has help the households a lot during critical economic condition.

\section{REFERENCES}

[1] Adger, N.W., 2000. Social and EcologicalResilience:Are They Related?. Human Geography, 24: 3.

[2] Adger, N.W., P. Terry Hughes, Carl Folke, Stephen R. Carpenter, and Johan Rockstrom, 2005. Social-Ecological Resilience to Coastal Disasters. www.sciencemag.org Science., 309. 
[3] Alinovi, Luca.,Marco D’Errico, Erdgin Mane, and Donato Romano, 2010. Livelihoods Strategies and Household Resilience to Food Insecurity: an Empirical Analysis to Kenya. Paper Prepared For The Conference on "Promoting Resilience Through Social Protection in Sub-Saharan Africa", Organised by The European Report of Development in Dakar, Senegal, 28-30.

[4] Anonim, 2016. List of Lakes of Indonesia. Wikipedia.org/wiki/list_of_lakes_of_Indonesia. www.google.com

[5] Chambers, R. and G.R. Conway, 1991. Sustainable Rural Livelihoods: Practical Concepts for The 21st Century, (Institute of Development Studies, 1991); http://www.eldis.org/vfile/upload/1/document/0708/DOC12443.pdf

[6] BPS Wajo, 2013. Produksi Perikanan Kabupaten Wajodalam Angka. Badan Pusat Statistik, Pemerintah Kabupaten Wajo.

[7] Dharmawan, A.H., 2006. Sistem Penghidupandan Nafkah Pedesaan Pandangan Sosiolog iNafkah (Livelihood Sociology) Mazhab Barat danMazhab Bogor. Sodality: Jurnal Transdisiplin Sosiologi, Komunikasi, dan Ekologi Manusia. 01(02)

[8] Ellis, F., 2000. Rural Livelihoods and Diversity in Developing Countries. New York [US]: Oxford University.

[9] Endfield, Georgina, H., 2011. The Resilience and Adaptive Capacity of Social-Environmental Systems in Colonial Mexico. Proceedings of The National Academy of Sciences of The United State of America, 109 no. 10/THN $2011: 3676-3681$

[10] Halima, A.S., S.Bulkis, Darmawan Salman, B.D. Eymal and Muhammad Arsyad, 2016. Socio-Economic Meanings Of Agricultural Land Conversion For Airport Area Development Of Farmers. Advances in Environmental Biology, 10(6): 39-48.

[11] Hang, N.T., Tran Huu Cuong, Nguyen Thi Khanh Hong, Hossein Azadi and Philippe Lebailly, 2016. Factors contributing to household-resilience capacity to farming risks: Casestudy ofclam farming in Thai Binhprovince, Vietnam. https://orbi.uliege.be/handle/2268/199779.

[12] Hermawan, F.K., A. Krisbandono, M.A. Hakim, M. Suriadi, Mahida and D.M. Hartati, 2015. Policy Brief :Pemetaan Sosial Ekonomidan Lingkungan: Mendukung Pengembangan Kawasan dan Konservasi Ekosistem Danau Tempe Sulawesi Selatan. Pusat Litbang Kebijakandan Penerapan Teknologi Kementerian PU danPerumahan Rakyat, Jakarta.

[13] Huai, Jianjun, 2016. Role of Livelihood Capital in Reducing Climatic Vulnerability : Insight of Australian Wheat From 1990 - 2010. PLoS One. 2016; 11(3).

[14] Kafumbata, Dalitso., Daniel Jamu, SostenChiotha, 2014. Riparian Ecosystem Resilience and Livelihood Strategies Undertest : Lessons From Lake Chilwa in Malawi and Other Lakes in Africa. Biological Sciences, 369: 1639.

[15] Miles, M.B. and A.M. Huberman, 1984. Qualitative Data Analysis : A Sourcebook of New Methods. Newbury Park, CA-sage.

[16] Muliawan, Irwan., 2008. Socio-economic Study For Capture Fisheries Development in Lake Tempe Basin. Journal of Geospacial Information-Globe, 10(1): $11-18$.

[17] Nawrotzki, Raphael J., Lori M. Hunter, and Thomas W. Dickinson, 2012. Rural Livelihoods and Access to Natural Capital: Differences Between Migrants and Non-Migrants in Madagascar. National Center for Biotechnology Information, Demogr Res., 26(10).

[18] Nguyen, V.K and James, Helen, 2013. Measuring Household Resilience to Floods : a Case study in the VietnameseMekong River Delta. Ecology and Society, 18(3).

[19] Okpara, Uche T., Lindsay C. Stringer, and Andrew J. Dougill, 2016. Lake Drying and Livelihood Dynamics in Lake Chad : Unravelling The Mecanisms, Contexts and Responses. Ambio, 45(7): 781-795.

[20] Saraswati, Y. dan Dharmawan, 2014. The Livelihood Resilience of Forest Community Farmer Household in Giriwoyo, Wonogiri. Sodality, 02(01): 63-75.

[21] Soeprobowati, T.R., 2015. Integrated Lake Basin Manajement For Save Indonesian Lake Movement. Procedia Environmental Sciences, 23: 368-374.

[22] Surur, Fadhil., 2014. Analysis and Direction of Regional Development of Lake Tempe, south Sulawesi Province With Regard To Local Wisdom. Thesis. Bogor Agricultural University, Indonesia.

[23] Tanner, T., D. Lewis, D. Wrathall, R. Bronen, N. Cradock-Henry, S. Huq, C. Lawless, R. Nawrotzki, V. Prasad, Md. A. Rahman, R. Alaniz, K. King, K. McNamara, Md. Nadiruzzaman, S. Henly-Shepard and F. Thomalla, 2015. Livelihood Resilience in The Face of Climate Change. Nature Climate Change 5: 23-26.doi:10.1038/nclimate2431http://www.nature.com/nclimate/journal/v5/n1/full/nclimate2431.html

[24] Tantu, Andi Gusti., Nurkaidah, and Suryawati Salam, 2017. Tempe Lake and Various Problems. Journal of FisheriesSciences.com on $24^{\text {th }}$ October 2017.

[25] Turasihdan Adiwibowo, 2012. Sistem Nafkah Rumahtangga Petani Kentang di Dataran Tinggi Dieng. Sodality. Jurnal Transdisiplin Sosiologi Komunikasidan Ekologi Manusia, 06(02): 196-107.

[26] Twine, Wayne, 2013. Multiple Strategies for Resilient Livelihoods in Communal Areas of South Africa.Afr J Range Forage Sci., 30(1-2): 39-43.

[27] Walker, B., C.S. Holling, S.P. Carpenter, A. Kinzig, 2004. Resilience, Adaptability, and Transformability in Social-Ecological System. Economy and Society, $9: 2$. 